\title{
EVALUATION OF EFFICIENCY OF PERENNIAL GRASS CULTIVATION ON BASIS OF FUZZY-POSSIBILITY MODEL
}

\author{
Alexey Sukhoparov, Aleksandr Spesivtsev \\ Saint-Petersburg Institute for Informatics and Automation of RAS, Russia \\ sukhoparov_ai@mail.ru,sav2050@gmail.com
}

\begin{abstract}
Based on the published studies of authors from different countries, it is concluded that it is necessary to develop new methodological principles for processing flows of heterogeneous numerical information and building models for agriculture. Moreover, the availability of numerical data on a variety of different variables does not compensate for the lack of effective methods of processing them for practical use by farmers when making decisions on pressing issues. The relevance of using the specialist's expertise which makes it possible to improve technological processes in the cultivation of perennial grasses is demonstrated. An example of the application of a new methodology for constructing a multi-factor mathematical model based on the convolution of explicit and implicit expert knowledge as one of the most effective methods of digitalization of agricultural production in conditions of uncertainty is given. The possibility of increasing the volume of grass stand biomass in a number of farms without additional resources up to $12 \%$ and up to $35 \%$ due to the use of material and technical resources with the maximum content of nutrients in the grass during its mowing has been shown. In addition, it will help reduce the specific cost of metabolizable energy in grass by 1.14 time.
\end{abstract}

Keywords: grass feed, expert knowledge, grass cultivation, efficiency assessment, fuzzy probability models.

\section{Introduction}

The solution to the problem of providing the population with affordable, environmentally friendly food in sufficient volume should be based on the maximum use of natural and climatic resources, taking into account the biopotential of plants, and the rational use of available material and labour resources.

All over the world, significant areas are occupied by forage ecosystems (pastures and hayfields, perennial and annual grasses): about $33 \%$ of agricultural land is occupied by forage crops in the EU, and in some parts of the world, in particular in the North-West region of Russia, they account for 9/10 of the total area of sown and agricultural land $[1 ; 2]$. At the same time, forage production contributes to effective crop rotations and an increase in the yield of many crops, a decrease in negative processes of erosion and loss of humus, and an increase in soil fertility. These circumstances turn fodder production into the largest and most multifunctional branch of agriculture. One of the main obstacles for a good forage supply is the realization of the biological potential of grasses, which is achieved by the timely implementation of the best available technological operations in the cultivation of grasses. In addition, feeding animals with forage obtained as a result of the early mowing phases and multiple mowing contributes to an increase in their productivity [3; 4].

An extensive review [5], devoted to modeling and information processing in the field of agriculture, draws conclusions about the weak efficiency of pair dependences and the need to develop new methodological techniques for converting heterogeneous information flows into multidimensional dependencies. This would make it possible to more accurately investigate, for example, not only the individual qualities of feed on milk yield, but also to build expert systems with the interaction of a larger number of important variables. At the same time, the work [6] indicates that in the agri-food sector, high hopes are put on the Internet of the future, but it is not yet known how to implement them.

The cultivation of perennial grasses includes operations for pre-sowing seed treatment, soil preparation and sowing, and as well as caring for them (top dressing, protection from weeds, insects and diseases). A change in even one factor can significantly cause not only the shortage of grass harvest, but also affect the technology, which was previously optimal for realizing the biological potential of herbs. The use of intensive agro-technological solutions in the cultivation of grasses leads to a change in their qualitative parameters and forms the output indicators of the technological process, which makes it possible to assess the value of the efficiency from their implementation.

Due to the large number of factors and conditions that form the quantitative and qualitative indicators of herbs, the experts are in conditions of significant uncertainty and it is difficult for them to make rational technical and technological decisions in real time. 
The purpose of this study is to build a multi-factor fuzzy probability model based on expert knowledge to assess the effectiveness of the decision made when cultivating perennial grasses in conditions of uncertainty.

\section{Materials and methods}

The fuzzy-probability method is the result of the development of a new methodology for constructing mathematical models of the state of processes, objects and phenomena based on explicit and implicit expert knowledge [7]. In this case, the expert is considered as an "intelligent measuring and diagnostic system". When solving the problem, the expert first chooses the factor space for solving this problem, then considers the solution options and, depending on the situation, gives a solution. Psychologists have found that a person thinks in words, not numbers. It is more convenient for an expert to present verbal formulations in the form of linguistic variables, for example, yield is "low", "medium", "high". These estimates are arranged on the scales of linguistic variables, allowing them to be converted into quantitative values for subsequent processing by statistical methods. Possible situations of the studied phenomenon, in this case, the assessment of the efficiency of cultivation of perennial grasses, are set by the matrix according to the methods of the theory of planning experiments. Such a questionnaire matrix filled in by an expert provides the initial numerical material for constructing a mathematical mode.

Thus, the fuzzy-probability approach is a synthesis of elements of the theory of fuzzy sets (extracting and presenting expert knowledge) and the theory of planning experiments (setting a questionnaire matrix and building a mathematical model).

At the same time, it should be especially emphasized that the initial knowledge and experience of an expert are the starting points for constructing a mathematical model. The statistical farming data of previous years are only used to assess the degree of adequacy of the model synthesized by this method. The same adequacy of the model serves as an assessment of the expert qualifications on the problem under study.

The sequence of actions for the extraction and formalization of expert knowledge in agriculture is presented in the work $[7 ; 8]$. As shown in the appropriate methods, it is advisable to carry out systematic extraction and formalization of expert information in the form of mathematical polynomial models based on the fuzzy-probability approach.

The task of cultivating herbs, the diagram of which is shown in Fig. 1, involves the implementation of a number of technical and technological decisions aimed at obtaining green mass $(Y)$ :

- $X_{1}$ - category of grass seeds;

- $X_{2}$ - operations for pre-sowing seed treatment;

- $X_{3}$ - agrotechnical measures for the care of herbs;

- $X_{4}$ - operations for feeding herbs;

- $X_{5}$ - operations to protect forage lands from weeds, insects and diseases;

- $X_{6}$ - period of herbage use.

$Y$ is a generalized indicator of the effectiveness of technical and technological solutions in the cultivation of herbs, expressed through the yield of grass, a qualitative variable.

In this study, $Y$ is considered as a possible achievement of the highest yield of green mass $\left(\mathrm{t} \cdot \mathrm{ha}^{-1}\right)$ when using the entire biological potential of a certain variety and type of grass.

These variables are characterized by a multitude of information flows for various purposes with different levels of discreteness, reliability, accuracy and other metrological characteristics, which complicates the description and quantitative assessment of the soil resource.

Variables $X_{1}-X_{6}$ are different by their physical nature and are determined most often by nonquantitative (verbal) values that cannot be unambiguously determined. Therefore, according to the fuzzy-probability approach using expert knowledge and experience in agriculture [8], it is advisable to express the selected factor space in the form of linguistic variables, as shown in Fig. 2. 


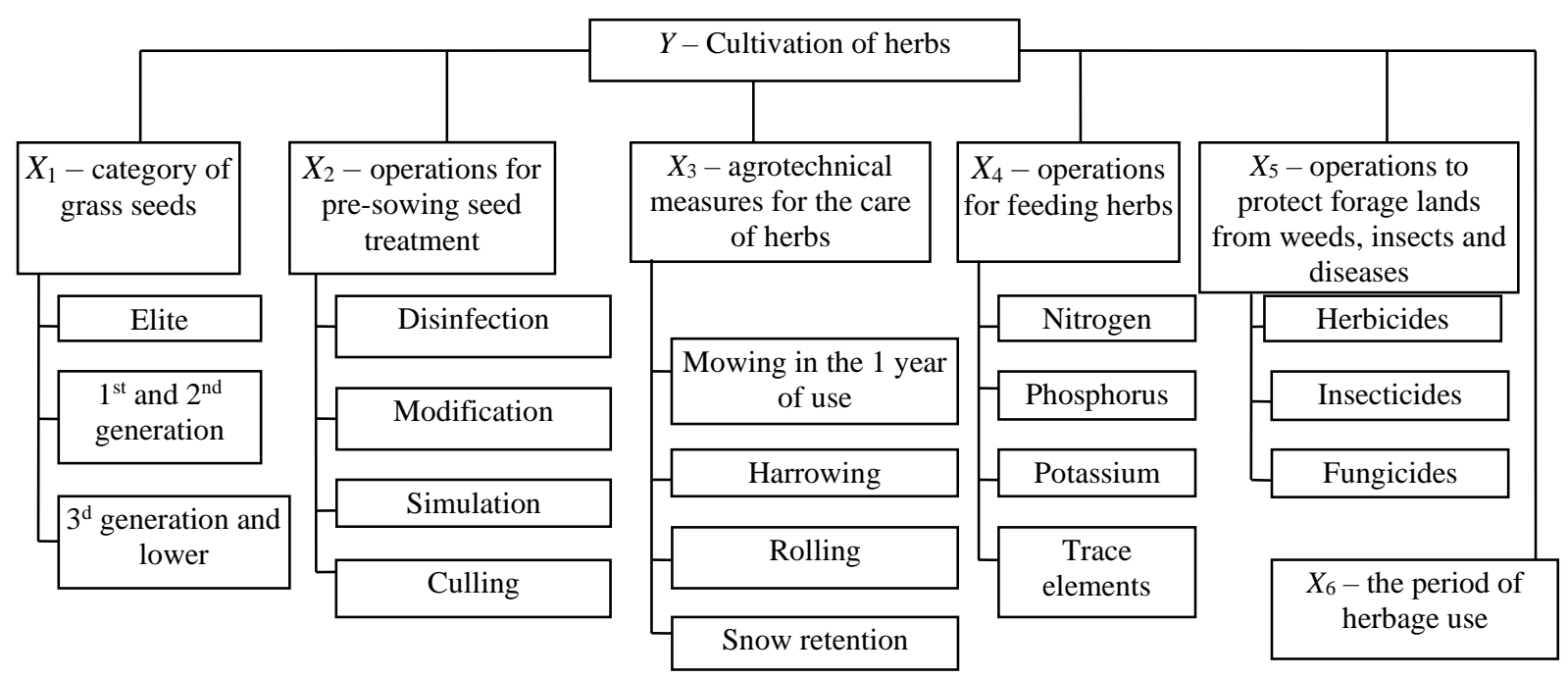

Fig. 1. Technical and technological solutions for cultivation of perennial grasses

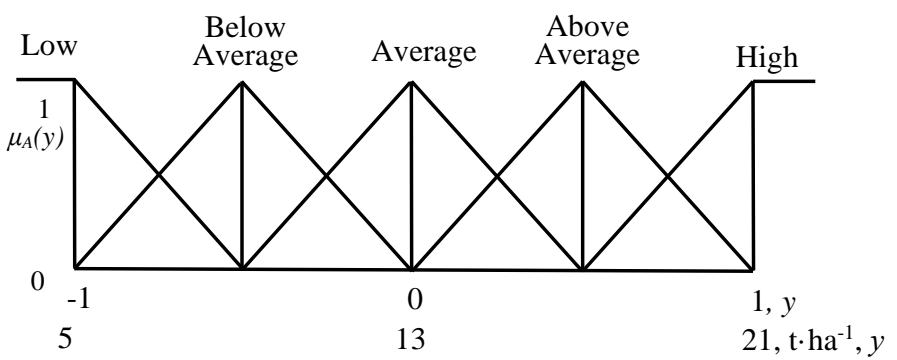

Fig. 2. General view of the linguistic variable

Formalization of the influence of each of the considered indicators in their aggregate interaction is determined through the rating scale, i.e. by translating verbal expressions of the significance of a separate criterion, according to the expert, into numerical form. So, the lower scale in Fig. 2 shows the interval of variation of the generalized indicator $Y$ from 5 to $21 \mathrm{t} \cdot \mathrm{ha}^{-1}$. At the same time, the yield level of less than $5 \mathrm{t} \cdot \mathrm{ha}^{-1}$ means that the technological process of grass cultivation is carried out using seeds for sowing $\left(X_{1}\right)$ generations with reproduction below 3 without pre-sowing treatment $\left(X_{2}\right)$, in the absence of agrotechnical measures $\left(X_{3}\right)$, top dressing $\left(X_{4}\right)$ and very strong infestation of the herbage with insects or diseases (more than 50\%) and weediness (more than 45\%) $\left(X_{5}\right)$ with a period of use of the grass of more than 12 years. The upper level assumes (obtaining a yield of green mass of more than $21 \mathrm{t} \cdot \mathrm{ha}^{-1}$ ) the use of seeds from the selected category $\left(X_{1}\right)$, pre-sowing seed treatment includes their disinfection + modification + stimulation + culling $\left(X_{2}\right)$, agrotechnical measures include harrowing + rolling + snow capture $\left(X_{3}\right)$, top dressing is carried out in the spring with nitrogen fertilizers with an application of 40-90 kg $\cdot \mathrm{ha}^{-1}$ a.i. + nitrogen $40-60 \mathrm{~kg} \cdot \mathrm{ha}^{-1}$ a.i. after 1 hay crop + phosphorus and potash 20-60 kg. ha ${ }^{-1}$ a.i. in the autumn $\left(X_{4}\right)$, no infestation by insects or diseases and very low weediness (up to $1 \%)\left(X_{5}\right)$ with a period of use of grass stand of less than 3 years.

It is advisable to extract such expert knowledge with the aim of further formalizing it through special questionnaire matrices based on the theory of planning experiments, a fragment of which is shown in Table 1. In Table 1, the values "-1" and "+1" correspond to the "lower" and "upper" levels for each of the variables, as shown on the lower abscissa for $\mathrm{x}$ in Fig. 2.

Each row of the matrix represents a production rule of the implicative type "if ..., then ..." and corresponds to a certain situation, which the expert evaluates $Y_{e}$ at the verbal level according to the upper scale in Fig. 2. 
Fragment of the survey matrix with expert estimates and model calculations

\begin{tabular}{|c|c|c|c|c|c|c|c|c|c|}
\hline \multirow{3}{*}{ No. } & \multirow{3}{*}{$\begin{array}{c}\text { Cate } \\
\text { gory } \\
\text { of } \\
\text { grass } \\
\text { seeds } \\
x_{1} \\
\end{array}$} & \multirow{3}{*}{$\begin{array}{c}\text { Operations } \\
\text { for pre- } \\
\text { sowing } \\
\text { seed } \\
\text { treatment } \\
x_{2} \\
\end{array}$} & \multirow{3}{*}{$\begin{array}{c}\text { Agrotec } \\
\text { hnical } \\
\text { measur } \\
\text { es for } \\
\text { care of } \\
\text { herbs }\end{array}$} & \multirow{3}{*}{$\begin{array}{c}\begin{array}{c}\text { Operati } \\
\text { ons for } \\
\text { feeding } \\
\text { herbs }\end{array} \\
x_{4} \\
\end{array}$} & \multirow{3}{*}{ 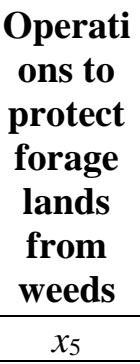 } & \multirow{3}{*}{$\begin{array}{c}\begin{array}{c}\text { Period } \\
\text { of } \\
\text { herba } \\
\text { ge use }\end{array} \\
x_{6} \\
\end{array}$} & \multirow{2}{*}{\multicolumn{3}{|c|}{ Grass yield $Y$}} \\
\hline & & & & & & & & & \\
\hline & & & & & & & $Y_{e}$ & $Y_{e}$ & $Y$ \\
\hline 1 & -1 & -1 & -1 & -1 & -1 & -1 & $\mathrm{~L}$ & 5 & 4.62 \\
\hline 2 & 1 & -1 & -1 & -1 & -1 & 1 & BA-A & 11 & 10.2 \\
\hline 3 & -1 & 1 & -1 & -1 & -1 & 1 & $\mathrm{BA}$ & 9 & 9.50 \\
\hline$\ldots$ & $\ldots$ & $\ldots$ & $\ldots$ & $\ldots$ & $\ldots$ & $\ldots$ & $\ldots$ & $\ldots$ & $\ldots$ \\
\hline 62 & 1 & -1 & 1 & 1 & 1 & -1 & $\mathrm{AA}$ & 17 & 16.6 \\
\hline 63 & -1 & 1 & 1 & 1 & 1 & -1 & A-AA & 15 & 14.8 \\
\hline 64 & 1 & 1 & 1 & 1 & 1 & 1 & $\mathrm{H}$ & 21 & 20.5 \\
\hline
\end{tabular}

A survey table of experts with an assessment of the degree of influence of variables with their extreme values, characteristic of the North-West of Russia, determines a generalized assessment of the yield of grasses $Y$.

\section{Results and discussion}

According to the developed methodology, the verbal expert values on the scales in Fig. 2 are converted into numerical ones and represent the source material for building a model. So, after the appropriate computer processing according to a special program, an expression of the feed resource was obtained, taking into account the degree of influence of all its forming factors:

$$
\begin{aligned}
Y & =12.253+1.813 x_{1}+1.188 x_{2}+0.313 x_{3}+2.438 x_{4}+1.188 x_{5}+1.438 x_{6}- \\
& -0.563 x_{1} x_{2}+0563 x_{1} x_{3}+0.313 x_{2} x_{4}-0.313 x_{3} x_{4}-0.438 x_{1} x_{2} x_{5},
\end{aligned}
$$

where the summands are given only with significant coefficients, and the variables are presented on a standardized scale.

The analysis of the polynomial model (1) allows us to conclude that the greatest influence on the formation of green biomass in the cultivation of herbs is exerted by mineral fertilization $X_{4}$ ), as well as effective pre-sowing treatment of seeds $\left(X_{2}\right)$ and subsequent operations related to the protection of crops from weeds, pests and diseases $\left(X_{5}\right)$. The sowing category of seeds $\left(X_{1}\right)$ and the period of use of the grass stand $\left(X_{6}\right)$ also play a significant role. Thus, mineral fertilization, pre-sowing seed treatment and plant protection measures make it possible to significantly increase the yield of the green mass of perennial grasses for animal feed, and not only by carrying out crop rotation and liming the soil.

The results of an expert assessment $\left(Y_{e}\right)$ of the effectiveness of the implementation of technical and technological decisions in the cultivation of perennial grasses according to model (1) in the farms of Leningrad region are shown in Table 2, where the values of the variables are given on a verbal scale.

As follows from the calculations in Table 2, the high efficiency of the application of all technical and technological decisions in the cultivation of perennial grasses in the farm F1, according to the scale in Figure 2, is close to the AA term. In other words, in this economy, the retention of almost all types of technological operations shown in Fig. 1, at high levels allows for high yields of herbs. The yield in the F2 farm is closer to the A term, and in the F3 farm to the BA. Thus, in the last two farms, there is a significant potential for increasing yields by increasing at least one of the indicators of the factor space, for example, more reproductive seeds or a greater number of pre-sowing treatments, agrotechnical measures for caring for crops in the early spring period, etc. 
Evaluation of efficiency of cultivation of perennial grasses

\begin{tabular}{|c|c|c|c|c|c|c|c|c|}
\hline \multirow{2}{*}{ Farm } & $\begin{array}{c}\text { Categ } \\
\text { ory of } \\
\text { grass } \\
\text { seeds }\end{array}$ & $\begin{array}{c}\text { Operations } \\
\text { for pre- } \\
\text { sowing seed } \\
\text { treatment }\end{array}$ & $\begin{array}{c}\text { Agrotec } \\
\text { hnical } \\
\text { measur } \\
\text { es for } \\
\text { care of } \\
\text { herbs }\end{array}$ & $\begin{array}{c}\text { Operati } \\
\text { ons for } \\
\text { feeding } \\
\text { herbs }\end{array}$ & $\begin{array}{c}\text { Operations } \\
\text { to protect } \\
\text { forage } \\
\text { lands from } \\
\text { weeds }\end{array}$ & $\begin{array}{c}\text { Period } \\
\text { of } \\
\text { herbage } \\
\text { use }\end{array}$ & \multicolumn{2}{|c|}{ Grass yield Y } \\
\cline { 2 - 9 } & $X_{1}$ & $X_{2}$ & $X_{3}$ & $X_{4}$ & $X_{5}$ & $X_{6}$ & $Y$ & $Y_{e}$ \\
\hline F1 & AA & AA & AA & AA-H & A-AA & H & 17.73 & AA \\
\hline F2 & A & A-AA & A-AA & A-AA & A & A & 13.59 & A \\
\hline F3 & BA & L-BA & BA & A & BA & L-BA & 9.908 & BA \\
\hline
\end{tabular}

The calculations performed according to the model (1) show that due to the redistribution of resources, it is possible to increase the yield of green biomass. Thus, the most effective technical and technological decision will be considered the refusal to implement a number of agrotechnical measures and increase the doses of mineral fertilization, which will increase the effect to $11.5 \%$, and the mobilization of small material resources for operations to modify seeds (scarification or removing the awns from grain ) during pre-sowing treatment will contribute to an increase in the yield of grasses by $4.8 \%$ and a decrease in the cost of a unit of exchange energy in grass by over 1.035 times.

\section{Conclusions}

1. A practical example of the application of a new methodology for constructing a six-factor mathematical model based on the convolution of explicit and implicit expert knowledge as one of the most effective methods of digitalization of agricultural production in conditions of uncertainty is given.

2. A fuzzy-probability model, based on the expert's knowledge and experience, of the potential of grass yield for the conditions of the North-West of Russia has been built, which allows predicting the yield of green grass biomass when implementing specific technical and technological decisions.

3. The most effective technical and technological decisions for cultivation of perennial grasses are mineral fertilization and pre-sowing treatment of grass seeds with protective measures against weeds, pests and diseases, which contributes to an increase in the efficiency of the technological process of cultivation of perennial grasses without mobilizing resources to $11.5 \%$, and the use of small material resources only for operations to modify seeds (scarification or removing the awns from grain) during pre-sowing treatment will increase the yield of grasses by $4.8 \%$.

\section{References}

[1] Stypinski P. The Effect of Grassland-based Forages on Milk Quality and Quantity. Agronomy Research. 9. Special Issue II. 2011, pp. 479-488.

[2] Справочник по кормопроизводству. 5-е изд., перераб. и дополн. (Handbook of feed production. 5th ed., rev.) Под ред. В.М. Косолапова, чл.-корр. Россельхозаекадемии, доктора с-х. наук. И.А. Трофимова, доктора географ. наук. - М.: Россельхозакадемия, 2014. 717 p. (In Russian).

[3] Flaten O., Bakken A. K., Randby A. T. The profitabilityof harvesting grass silages at early maturity stages: An analysis of dairy farming systems in Norway. Agricultural Systems. Vol. 136. 2015, Jun, pp. 85-95. DOI: 10.1016/j.agsy.2015.03.001

[4] Meripõld H., Tamm U., Tamm S., Võsa T., Edesi L. Fodder galega (Galega orientalis Lam) grass potential as a forage and bioenergy crop. Agronomy Research. 15(4). 2017, pp. 1693-1699. DOI: 10.15159/AR.17.021.

[5] O 'GradyM.J., Hare G.M.P.O. Modelling the smart farm. Information Processing in Agriculture. Volume 4, Issue 3, September 2017, pp. 179-187.

[6] Lehmann R.J., Reiche R., Schiefer G. Future internet and the agri-food sector: State-of-the-art in literature and research Comp Electron Agric, 89 (2012), pp. 158-174

[7] Игнатьев М.Б., Марлей В.Е., Михайлов В.В., Спесивцев А.В. Моделирование слабо формализованных систем на основе явных и неявных экспертных знаний (Modeling weakly 
formalized systems based on explicit and implicit expert knowledge). СПб : ПОЛИТЕХ-ПРЕСС, 2018. 430 p. (In Russian).

[8] Popov V.D., Spesivtsev A.V., Sukhoparov A.I., Spesivtsev V.A. Use of logical-linguistic models to predict the retained biological potential of grasses during their conservation. Proceedings of the 19th International Conference on Soft Computing and Measurements, SCM 2016. Russia, June 2224, 2016, Revised Selected Papers, 2016, pp. 244-246. 